\title{
The American Association for Thoracic Surgery consensus guidelines on bicuspid aortic valve-related aortopathy: Executive summary
}

\author{
Michael A. Borger, MD, PhD, ${ }^{a}$ Paul W. M. Fedak, MD, PhD, ${ }^{b}$ Elizabeth H. Stephens, MD, PhD,
}

Thomas G. Gleason, MD, ${ }^{\mathrm{d}}$ Evaldas Girdauskas, MD, PhD, ${ }^{\mathrm{e}}$ John S. Ikonomidis, MD, PhD,

Ali Khoynezhad, MD, PhD, ${ }^{g}$ Samuel C. Siu, MD, ${ }^{\mathrm{h}}$ Subodh Verma, MD, PhD, ${ }^{\mathrm{i}}$ Michael D. Hope, MD,

Duke E. Cameron, MD, ${ }^{\mathrm{k}}$ Donald F. Hammer, MD, ${ }^{1}$ Joseph S. Coselli, MD, ${ }^{\mathrm{m}}$ Marc R. Moon, MD, ${ }^{\mathrm{n}}$

Thoralf M. Sundt, MD, ${ }^{\circ}$ Alex J. Barker, PhD ${ }^{\mathrm{p}}$ Michael Markl, PhD, ${ }^{\mathrm{q}}$ Alessandro Della Corte, MD, PhD,

Hector I. Michelena, MD, ${ }^{\mathrm{s}}$ and John A. Elefteriades, $\mathrm{MD}^{\mathrm{t}}$

\begin{abstract}
Bicuspid aortic valve disease is a common congenital cardiac disorder, being present in $1 \%$ to $2 \%$ of the general population. Associated aortopathy is a common finding in patients with bicuspid aortic valve disease, with thoracic aortic dilation noted in approximately $40 \%$ of patients in referral centers. Several previous consensus statements and guidelines have addressed the management of bicuspid aortic valve-associated aortopathy, but none focused entirely on this disease process. The current document is an executive summary of "The American Association for Thoracic Surgery Guidelines on Bicuspid Aortic Valve-Related Aortopathy." All major aspects of bicuspid aortic valve aortopathy, including natural history, phenotypic expression, histology and molecular pathomechanisms, imaging, indications for surgery, surveillance, and follow-up, and recommendations for future research are contained within these guidelines. The current executive summary serves as a condensed version of the guidelines to provide clinicians with a current and comprehensive review of bicuspid aortic valve aortopathy and to guide the daily management of these complex patients. (J Thorac Cardiovasc Surg 2018;156:473-80)
\end{abstract}

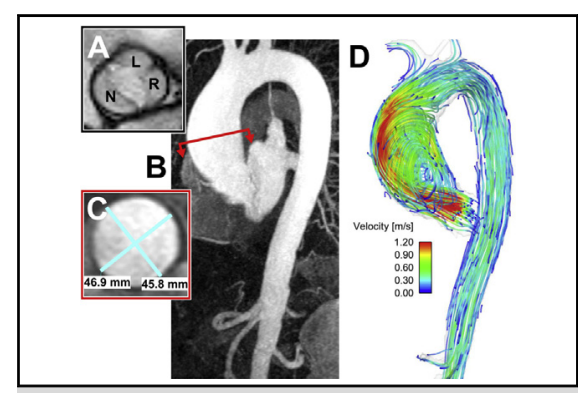

Typical patient with BAV with associated aortopathy.

Central Message

The current document is an executive summary of "The American Association for Thoracic Surgery Guidelines on Bicuspid Aortic Valve-Related Aortopathy."

Perspective

BAV-related aortopathy is a common clinical entity. An increasing amount of literature has recently shown that BAV aortopathy is less dangerous than previously described. The current Executive Summary is a condensed version of the "American Association for Thoracic Surgery Guidelines on Bicuspid Aortic Valve-Related Aortopathy," providing clinicians with a current and comprehensive review of BAV aortopathy and its management.

See Editorial Commentary page 481

See Editorial page 467

\begin{abstract}
From the ${ }^{\text {a}}$ Leipzig Heart Center, Cardiac Surgery, University of Leipzig, Leipzig,

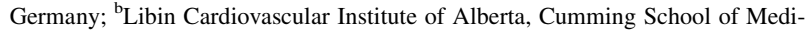
cine, University of Calgary, Calgary, Alberta, Canada; 'Columbia University, New York, NY; ${ }^{\mathrm{d} D i v i s i o n}$ of Cardiac Surgery, Department of Cardiothoracic Surgery, University of Pittsburgh Medical Center, Pittsburgh, Pa; ${ }^{\mathrm{e} D e p a r t m e n t ~ o f ~ C a r-~}$ diovascular Surgery, University Heart Center Hamburg, Hamburg, Germany; ${ }^{\mathrm{f}}$ Division of Cardiothoracic Surgery, University of North Carolina, Chapel Hill, NC; ${ }^{g}$ Memorial Care Heart and Vascular Institute, Memorial Care Long Beach Medical Center, Long Beach, Calif; ' ${ }^{\text {S }}$ chulich School of Medicine \& Dentistry, Western University, London, Ontario, Canada; ${ }^{\mathrm{i} D e p a r t m e n t ~ o f ~ C a r d i a c ~ S u r g e r y, ~}$ St. Michael's Hospital, University of Toronto, Toronto, Ontario, Canada; ${ }^{j}$ San Francisco (UCSF) Department of Radiology \& Biomedical Imaging, University of California, San Francisco, Calif; ' ${ }^{2}$ Department of Cardiac Surgery, Massachu-

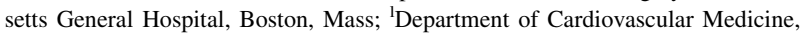
Cleveland Clinic, Cleveland, Ohio; ${ }^{\mathrm{m}}$ Division of Cardiothoracic Surgery, Texas Heart Institute, Baylor College of Medicine, Houston, Tex; ${ }^{\mathrm{n} S e c t i o n}$ of Cardiac
\end{abstract}

Surgery, Washington University School of Medicine, St Louis, Mo; ${ }^{\circ}$ Division of Cardiac Surgery, Massachusetts General Hospital, Boston, Mass; ${ }^{\mathrm{p}}$ Department of Radiology, Feinberg School of Medicine, Northwestern University, Chicago, Ill; ${ }^{\mathrm{q}}$ Departments of Radiology and Biomedical Engineering, Feinberg School of Medicine, Northwestern University, Chicago, Ill; ' ${ }^{\mathrm{D}}$ Department of Cardiothoracic Sciences, Second University of Naples, Naples, Italy; ${ }^{\mathrm{S}}$ Department of Cardiovascular Medicine, Mayo Clinic, Rochester, Minn; and 'Department of Cardiothoracic Surgery, Yale University School of Medicine, New Haven, Conn.

Received for publication April 6, 2017; revisions received Sept 19, 2017; accepted for publication Oct 16, 2017.

Address for reprints: Michael A. Borger, MD, PhD, University Director of Cardiac Surgery, Leipzig Heart Center, Struempellstrasse 39, 04289 Leipzig, Germany (E-mail: michael.borger@helios-gesundheit.de). $0022-5223 / \$ 36.00$

Copyright $\odot 2018$ by The American Association for Thoracic Surgery https://doi.org/10.1016/j.jtcvs.2017.10.161 


\section{TABLE OF CONTENTS}

Introduction . . . . . . . . . . . . . . . . . . .474

Epidemiology, Pathophysiology, and Clinical Phenotypes . .474

Aortic Imaging . . . . . . . . . . . . . . . . . . . . .474

Aortic Imaging Surveillance. . . . . . . . . . . . . 475

Surgical Management . . . . . . . . . . . . . . . 4475

Indications for Aortic Repair in Patients With Bicuspid

Aortic Valve With Significant Aortic Valve Dysfunction . . 475

Indications for Aortic Repair in Patients With Bicuspid

Aortic Valve Without Significant Aortic Valve Dysfunction 476

Management of Aortic Arch. . . . . . . . . . . . . . . 477

Medical Management . . . . . . . . . . . . . . . . . . . . 477

Follow-up Aortic Imaging . . . . . . . . . . . . . . . . 477

Medical Management and Watchful Waiting. . . . . . . 478

Family Screening . . . . . . . . . . . . . . . . 479

Conclusions . . . . . . . . . . . . . . . . . . . . . . . . . .479

Conflict of Interest Statement . . . . . . . . . . . . . . . . . 479

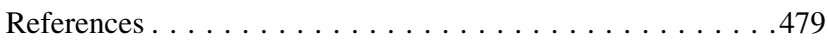

INTRODUCTION

Bicuspid aortic valve (BAV) disease is the most common congenital cardiac disorder, being present in $1 \%$ to $2 \%$ of the general population. ${ }^{1}$ Associated aortopathy is a common finding in patients with BAV disease, with thoracic aortic dilation noted in approximately $40 \%$ of patients in referral centers. Several previous documents have addressed the management of BAV-associated aortopathy, with one of the first being a set of multisocietal guidelines published in $2010 .^{2-8}$ Of these prior publications, none focused entirely on patients with BAV aortopathy. Therefore, the current Consensus Statement differs in that it covers all major aspects of BAV aortopathy, including its natural history, phenotypic expression, histology and molecular pathomechanisms, imaging, indications for surgery, surveillance and follow-up, and recommendations for future research. It aims to provide clinicians with a current and comprehensive review of BAV aortopathy and to guide the daily management of these complex patients. The full Consensus Statement can be found online, and the current document serves as its executive summary (please see full-length document on pages e41-e74 in this issue).

\section{EPIDEMIOLOGY, PATHOPHYSIOLOGY, AND CLINICAL PHENOTYPES}

Contemporary clinical outcomes for patients with BAV have been summarized in a comprehensive table by Michelena and colleagues ${ }^{9}$ from the International BAV Consortium (see Table 2 in the full-length document on pages e41-e74 in this issue). These data show excellent overall survival of patients with BAV in community, populationbased studies, whereas outcomes are not as good in patients who have required aortic valve replacement (AVR). Heart failure is particularly uncommon in patients with BAV, and aortic stenosis is a more common indication for surgery than aortic insufficiency. Thoracic aortic aneurysm formation (aortic diameter $>45 \mathrm{~mm}$ ) occurs in $25 \%$ to $45 \%$ of patients over prolonged periods of follow-up. However, aortic dissection is a rare event $(\sim 1 \%)$ outside of tertiary referral center populations, in whom it is more common $(\sim 10 \%))^{9}$

The evidence of phenotypic heterogeneity of BAV aortopathy has emerged in the last decade from several observational studies and has stimulated a critical reappraisal of the literature and treatment recommendations. The proposed hypothesis is that different types of BAV aortopathy (ie, so-called aortic phenotypes) may be caused by distinct pathogenetic mechanisms and therefore require individualized surgical approaches. ${ }^{10,11}$ In particular, the 2 longdebated theories on BAV-aortopathy pathogenesis, namely, the genetic and hemodynamic theories, could both be plausible inasmuch as different phenotypic forms might be variable expressions of both causative factors. Phenotypic heterogeneity of BAV aortopathy also may explain some of the inconsistencies in published natural history and follow-up studies, especially regarding the risk of aortic events in BAV disease. Previous data from mixed BAV cohorts resulted in a wide variety of suggested surgical treatments, ranging from very conservative approaches to very aggressive recommendations, usually extrapolated from guidelines for management of patients connective tissue disorders (eg, Marfan syndrome). ${ }^{3}$ Clinicians' thresholds for surgical intervention of $\mathrm{BAV}$-associated aortopathy have been similarly diverse and sometimes inconsistent with consensus opinion and guidelines. ${ }^{12}$

\section{AORTIC IMAGING}

Transthoracic echocardiography (TTE) is the recommended imaging modality for the initial assessment of the aortic valve and thoracic aorta, including the assessment of hemodynamic aortic valve function ${ }^{13}$ (Table 1). If any part of the aorta is dilated or complete examination of the aorta is not possible by TTE, computed tomography (CT) or magnetic resonance imaging (MRI) is recommended. Hemodynamic aortic valve assessment also can be performed by MRI, although TTE remains the gold standard. TTE assessment of aortic valve function is usually sufficient, but transesophageal echocardiography should be performed in patients with unexplained left ventricular dilation or dysfunction. When evaluating the BAV aorta with echocardiography, the entire thoracic aorta should be assessed: aortic root (aortic annulus, sinuses of Valsalva and sinotubular junction), tubular ascending aorta (proximal, mid, and distal), aortic arch, and descending thoracic aorta, including diameter and Doppler assessment for the presence of coarctation.

Echocardiography-derived aortic root diameters greater than $40 \mathrm{~mm}$ should be verified by electrocardiogramgated CT or MRI (Table 1). Given that the sinuses can dilate asymmetrically, all 3 sinus-to-commissure (or sinus-tosinus) dimensions should be measured. ${ }^{14}$ The choice 
between CT and MRI is dependent on their availability, the institutional expertise, and the age of the patient. Younger patients (ie, aged $<50$ years) would benefit from MRI surveillance to avoid CT-associated radiation exposure. Ideally, interval measurements should be performed with the same imaging modality and same technique (ie, electrocardiogram-gated), and compared side-by-side by an experienced reader. ${ }^{13}$

\section{Aortic Imaging Surveillance}

In patients with initial aortic dilatation (root or tubular ascending aorta $40-49 \mathrm{~mm}$ ), the thoracic aorta should be reimaged at 12 months. If stability is confirmed, then reimaging can be performed every 2 or 3 years (Table 2). The first interval repeat measurement may be performed at 6 months before proceeding to yearly assessments, especially if other risk factors such as aortic coarctation or family history of dissection are present. In patients with more advanced initial aortic dilatation (root or tubular ascending aorta 50$54 \mathrm{~mm}$ ), the thoracic aorta should be reimaged at least every 12 months (yearly). As opposed to Marfan syndrome in which the aortic root is predominantly involved, the most common segment involved in patients with $\mathrm{BAV}$ is the tubular ascending aorta ${ }^{9}(60 \%-70 \%$ of BAV dilated aortas).

Aortic growth rates for the tubular ascending segment in adults with BAV have recently been reported to range from 0.4 to $0.6 \mathrm{~mm} / \mathrm{y},{ }^{15,16}$ whereas earlier studies demonstrated maximal dilatation rates of 1 to $2 \mathrm{~mm} / \mathrm{y}$. Few patients are observed to have a dilation rate greater than $2 \mathrm{~mm} / \mathrm{y}^{15,16}$ Although these represent "artificially annualized" rates, it remains unlikely that patients with BAV will dilate at more than $3 \mathrm{~mm} / \mathrm{y}$. It is also important to note that an interval diameter change of 1 or $2 \mathrm{~mm}$ is within the margin of error by current imaging modalities. Therefore, an interval dilatation of $3 \mathrm{~mm}$ or greater should be considered clinically significant. ${ }^{6}$ Absolute echocardiographic baseline aorta diameters do not reliably predict the rate of dilatation; thus, systematic interval imaging follow-up is required regardless of baseline diameter. Previous AVR is more common in patients with BAV presenting with aortic dissection, compared with patients with tricuspid aortic valve (TAV) with dissection. ${ }^{17}$ Therefore, continued interval monitoring of the unrepaired aorta post-AVR is suggested when there is evidence of aortopathy by surgical or radiologic examination.

\section{SURGICAL MANAGEMENT}

The most important clinical decision for patients with BAV-associated aortopathy is the appropriate timing of surgical intervention. Optimally, surgery should be recommended as soon as the risk of watchful waiting exceeds the risk of surgical intervention. Unfortunately, the precise time point when this occurs is sometimes difficult to identify because it is dependent on the individual patient, surgeon,
TABLE 1. Recommendations for initial imaging of the aorta in patients with bicuspid aortic valve

\begin{tabular}{|c|c|}
\hline Recommendation & Class/LOE \\
\hline $\begin{array}{l}\text { TTE is the initial imaging modality of choice for } \\
\text { assessment of the aortic valve and thoracic aorta in } \\
\text { patients with BAV. }\end{array}$ & $\mathrm{I} / \mathrm{C}^{3,18}$ \\
\hline $\begin{array}{l}\text { The entire thoracic aorta should be measured by TTE, } \\
\text { reporting each aortic segment separately in } \\
\text { millimeters: root (sinuses of Valsalva), sinotubular } \\
\text { junction, tubular ascending aorta (proximal, mid and } \\
\text { distal), arch and descending thoracic aorta. Maximum } \\
\text { diameter, regardless of location, should be reported. } \\
\text { Aortic coarctation should be ruled out with Doppler } \\
\text { evaluation of the descending thoracic aorta and } \\
\text { abdominal aorta. }\end{array}$ & $\mathrm{I} / \mathrm{C}^{3,5,18}$ \\
\hline $\begin{array}{l}\text { If TTE cannot visualize any aortic segment or any } \\
\text { segment measures } \geq 45 \mathrm{~mm} \text { or aortic coarctation } \\
\text { cannot be ruled out, recommend assessment of the } \\
\text { entire thoracic aorta with ECG-gated cardiac MRA or } \\
\text { CTA. }\end{array}$ & $I / C^{19,20}$ \\
\hline $\begin{array}{l}\text { If a patient is undergoing cardiac surgery and root or } \\
\text { tubular ascending aorta measure } 40-44 \mathrm{~mm} \text { by TTE, } \\
\text { recommend assessment of the thoracic aorta with } \\
\text { MRA or CTA before surgery. }\end{array}$ & $\mathrm{I} / \mathrm{C}^{17,19,20}$ \\
\hline $\begin{array}{l}\text { If aortic coarctation is present, screening for cerebral } \\
\text { aneurysms is recommended. }\end{array}$ & $\mathrm{I} / \mathrm{B}^{5}$ \\
\hline
\end{tabular}

and treatment center. Prophylactic aortic repair is recommended to prevent catastrophic aortic complications, that is, aortic dissection and rupture. Factors that should be considered when recommending aortic repair include maximum aortic diameter, presence of aortic risk factors (ie, rate of aortic growth, aortic wall thickness, BAV phenotype, uncontrolled hypertension, family history of aortic complications, or other aortic conditions such as coarctation or connective tissue disorders), presence of surgical risk factors (eg, advanced age, decreased left ventricular function, redo surgery), concomitant indications for cardiac surgery (most commonly aortic valvular stenosis or insufficiency), and surgeon/team experience and expertise.

\section{Indications for Aortic Repair in Patients With Bicuspid Aortic Valve With Significant Aortic Valve Dysfunction}

For patients with BAV and valve dysfunction significant enough to meet indications for aortic valve surgery, concomitant ascending aortic replacement is reasonable when the diameter exceeds $4.5 \mathrm{~cm}$ (Class IIa, level of evidence $\mathrm{C}$ in American Heart Association (AHA)/American College of Cardiology (ACC) 2014 guidelines, ${ }^{4}$ European Society of Cardiology (ESC) 2014 aortic guidelines, ESC valvular guidelines ${ }^{7}$ ) (Table 3 ). The incidence of aortic 
TABLE 2. Recommendations for interval monitoring imaging of the aorta in patients with bicuspid aortic valve

\begin{tabular}{|c|c|}
\hline Recommendation & Class/LOE \\
\hline $\begin{array}{l}\text { Interval imaging should be performed with the same } \\
\text { imaging technique and measurement method, and } \\
\text { compared side-by-side with previous study by an } \\
\text { expert in that imaging technique. }\end{array}$ & $\mathrm{I} / \mathrm{C}^{6,13,18}$ \\
\hline $\begin{array}{l}\text { Interval aorta imaging recommendations apply to } \\
\text { patients with native BAV and those who have } \\
\text { undergone AVR, given that aorta complications may } \\
\text { occur in patients with BAV postsurgery. }\end{array}$ & $\mathrm{I} / \mathrm{B}^{17,21}$ \\
\hline $\begin{array}{l}\text { In patients with normal initial aortic diameters by TTE, } \\
\text { the thoracic aorta should be reimaged every } 3 \text { to } 5 \mathrm{y} \text {. }\end{array}$ & $\mathrm{I} / \mathrm{C}^{13,15}$ \\
\hline $\begin{array}{l}\text { In patients with initial aortic dilatation (root or tubular } \\
\text { ascending aorta measure } 40-49 \mathrm{~mm} \text { ), the thoracic } \\
\text { aorta should be reimaged at } 12 \mathrm{mo} \text {. If stability is } \\
\text { confirmed, then reimaging can be performed every } 2 \\
\text { or } 3 \mathrm{y} \text {. }\end{array}$ & $\mathrm{I} / \mathrm{C}^{6,13,15,16}$ \\
\hline $\begin{array}{l}\text { In patients with more advanced initial aortic dilatation } \\
\text { (root or tubular ascending aorta } 50-54 \mathrm{~mm} \text { ), the } \\
\text { thoracic aorta should be reimaged at least every } 12 \text { mo } \\
\text { (yearly). }\end{array}$ & $\mathrm{I} / \mathrm{C}^{6,13,15}$ \\
\hline $\begin{array}{l}\text { If thoracic aortic dilation ( } \geq 45 \mathrm{~mm} \text { ) noted by TEE is not } \\
\text { reproducible with CTA or MRA (ie, }>2 \text {-mm difference } \\
\text { between modalities), then interval imaging follow-up } \\
\text { should be performed with MRA or CTA. }\end{array}$ & $\mathrm{I} / \mathrm{C}^{13,18}$ \\
\hline
\end{tabular}

$L O E$, Level of evidence; $B A V$, bicuspid aortic valve; $A V R$, aortic valve replacement; TTE, transthoracic echocardiography; TEE, transesophageal echocardiography; $C T A$, computed tomography angiography; $M R A$, magnetic resonance angiography.

dissection and other aortic catastrophes post-AVR is low, particularly in patients with BAV with aortic stenosis. ${ }^{19,22}$ Most patients with BAV undergoing AVR do not require complete aortic root replacement surgery. Indeed, the incidence of aortic root dilation post-AVR in patients with $\mathrm{BAV}$ is low, similar to the incidence in patients with TAV disease. ${ }^{23-25}$ Root replacement is reasonable to consider in patients with BAV undergoing AVR with an aortic root diameter exceeding $4.5 \mathrm{~cm}$.

The type of implanted valve at the time of AVR may influence the extent of aortic repair in patients with BAV. In patients with moderate aortic root dilation who have opted for a mechanical valve, complete root replacement may be considered. However, isolated AVR is preferable in young patients who have opted for a biological valve because of the low risk of subsequent aortic root rupture/dissection ${ }^{23,25}$ and the increased technical difficulty associated with repeat aortic root replacement surgery. ${ }^{26}$

Patients with bicuspid aortopathy and relatively normal aortic cusps with good mobility can be considered for valve-sparing aortic root replacement surgery (ie, David operation) in select centers (Table 3). Valve-sparing aortic root replacement in patients with BAV is technically challenging and should be performed by surgeons with substantial clinical experience in TAV patients. Aortic valve repair
TABLE 3. Recommendations for aortic repair in patients with bicuspid aortic valve aortopathy

\begin{tabular}{|c|c|}
\hline Recommendation & Class/LOE \\
\hline $\begin{array}{l}\text { Repair of the ascending aorta/root is recommended } \\
\text { when the aortic diameter is } \geq 55 \mathrm{~mm} \text { in patients } \\
\text { without risk factors. }\end{array}$ & $\mathrm{I} / \mathrm{B}^{13,20,39-41}$ \\
\hline $\begin{array}{l}\text { Repair of the ascending aorta/root should be performed } \\
\text { when the aortic diameter is } \geq 50 \mathrm{~mm} \text { in patients with } \\
\text { risk factors (ie, root phenotype or predominant aortic } \\
\text { insufficiency, uncontrolled hypertension, family } \\
\text { history of aortic dissection/sudden death, or aortic } \\
\text { growth }>3 \mathrm{~mm} / \mathrm{y} \text { ). }\end{array}$ & $\mathrm{IIa} / \mathrm{B}^{13,20,39-41}$ \\
\hline $\begin{array}{l}\text { Repair of the ascending aorta/root may be performed in } \\
\text { patients with an aortic diameter of } \geq 50 \mathrm{~mm} \text { when } \\
\text { the patients are at low surgical risk and operated on } \\
\text { by an experienced aortic team in a center with } \\
\text { established surgical results. }\end{array}$ & $\mathrm{IIb} / \mathrm{C}^{32,33}$ \\
\hline $\begin{array}{l}\text { Concomitant repair of the ascending aorta/root should } \\
\text { be performed when the aortic diameter is } \geq 45 \mathrm{~mm} \text { in } \\
\text { patients undergoing cardiac surgery. }\end{array}$ & $\mathrm{IIa} / \mathrm{B}^{13,19,39,42}$ \\
\hline $\begin{array}{l}\text { Repair of the aortic arch is recommended in patients } \\
\text { with an aortic arch diameter of } \geq 55 \mathrm{~mm} \text {. }\end{array}$ & $\mathrm{I} / \mathrm{B}^{36,43}$ \\
\hline $\begin{array}{l}\text { Concomitant repair of the aortic arch should be } \\
\text { performed in patients undergoing cardiac surgery } \\
\text { with an aortic arch diameter of } \geq 50 \mathrm{~mm} \text {. }\end{array}$ & $\mathrm{IIa} / \mathrm{C}^{44}$ \\
\hline $\begin{array}{l}\text { Concomitant repair of the aortic arch may be } \\
\text { performed in patients undergoing cardiac surgery } \\
\text { with an aortic arch diameter of } \geq 45 \mathrm{~mm} \text {, provided } \\
\text { the patients are at low surgical risk and operated on } \\
\text { by an experienced aortic team with established } \\
\text { surgical results. }\end{array}$ & $\mathrm{IIb} / \mathrm{C}^{45}$ \\
\hline $\begin{array}{l}\text { It is recommended that patients undergoing elective } \\
\text { aortic arch repair be referred to an experienced aortic } \\
\text { team with established surgical results. }\end{array}$ & $\mathrm{I} / \mathrm{B}^{37,38}$ \\
\hline
\end{tabular}

LOE, Level of evidence.

has been applied in carefully selected patients with BAV. Good midterm results for isolated aortic valve repair have been demonstrated in expert hands. ${ }^{27,28}$ However, the lack of long-term follow-up data and the increased technical complexity of aortic valve repair in patients with BAV have resulted in a lack of widespread adoption of these techniques.

\section{Indications for Aortic Repair in Patients With Bicuspid Aortic Valve Without Significant Aortic Valve Dysfunction}

Current guidelines recommend intervention on the aorta in patients with BAV without significant aortic valvular dysfunction (ie, valvular dysfunction does not meet criteria for surgical valve repair/replacement) if the maximal aortic diameter exceeds $5.5 \mathrm{~cm}$ and patients do not have any highrisk characteristics (Table 3) (Class I, level B in AHA/ACC guidelines $^{3,4}$ and Class I, level C in ESC 2014 guidelines $^{6}$ ). 
Such recommendations are based on the observation that $6.0 \mathrm{~cm}$ represents a definite inflection point in the risk of aortic complications and that natural history studies demonstrating a definitively increased risk of such complications in patients with BAV (in comparison with TAV) are debatable. Although Michelena and colleagues ${ }^{20}$ demonstrated that patients with BAV have a higher risk of aortic dissection than the general population, ${ }^{20}$ it is unknown at what aortic diameter these dissections tend to occur. It is also unknown whether a dilated BAV aorta is at greater risk than a dilated TAV aorta. Further complicating the issue, it has been observed that many patients with aortic dissection present with an aortic diameter of less than $5.5 \mathrm{~cm} .{ }^{29,30}$ Despite this finding, routine replacement of the ascending aorta in patients with an aortic diameter of less than $5.5 \mathrm{~cm}$ is not warranted because the size of the denominator is not known (ie, "aortic size paradox").

Certain factors may increase the risk of aortic complications in patients with BAV and therefore lead to an earlier recommendation for intervention. Current guidelines recommend surgical intervention at an aortic diameter of $5.0 \mathrm{~cm}$ in patients with any of the following risk factors: aortic coarctation, a family history of aortic dissection, or rapid aortic growth $(>3-5 \mathrm{~mm} / \mathrm{y})$. In the AHA/ACC 2014 valvular guidelines, this is a Class IIa, level of evidence $\mathrm{C}$ recommendation, ${ }^{4}$ and in the ESC 2014 aortic guidelines, this is a Class I, level $\mathrm{C}$ recommendation. ${ }^{6}$ Intervention at lower aortic diameters also can be considered in patients with small body surface area or stature, particularly if they have Turner syndrome. An indexed aortic diameter cutoff of greater than $2.75 \mathrm{~cm} / \mathrm{m}^{231}$ or an aortic crosssectional area to height ratio of greater than $10 \mathrm{~cm} / \mathrm{m}^{232}$ may be used to guide earlier surgical intervention in patients with small stature. Earlier intervention is occasionally justified in patients with a strong preference for early surgery. Finally, surgical repair may be performed at a lower threshold (ie, $5.0 \mathrm{~cm}$ ) if the patient has low operative risk and the procedure is performed by an experienced operative team with established results. ${ }^{2,3,32,33}$

These recommendations generally reflect a change toward a more conservative approach for BAV-associated aortopathy when compared with previous guidelines, which stated that such patients should be managed as aggressively as those with connective tissue disorders. ${ }^{3}$ Studies published subsequent to these earlier guidelines have demonstrated that patients with BAV have a markedly lower risk of aortic complication and aortic dilation than those with Marfan syndrome, with aortic catastrophe rates that are similar to rates in patients with TAV aneurysm. ${ }^{15,20,34,35}$ It is possible that some patients with BAV with distinct morphologic patterns of dilatation are at increased risk for complications. A recent joint statement of clarification was published to address the discrepancies in previously published guidelines. $^{8}$

\section{Management of Aortic Arch}

BAV disease and associated aortopathy have been the topics of multiple guidelines and consensus statements, but most do not address the aortic arch specifically. Neither the 2010 ACC/AHA guidelines ${ }^{3}$ nor the ESC Guidelines ${ }^{6}$ discuss indications for aortic arch repair in patients with BAV. The 2014 Canadian Cardiovascular Society Position statement was the first to recommend a threshold of $5.5 \mathrm{~cm}$ for replacement of aortic arch aneurysm associated with BAV. ${ }^{36}$

Indications for repair of the aortic arch should be no different in the setting of BAV compared with TAV. If a patient with BAV presents for AVR and has an ascending aortic aneurysm with a normal aortic diameter at the takeoff of the innominate artery, ascending aortic repair without arch intervention is recommended. If the aortic arch has a diameter of greater than $45 \mathrm{~mm}$ at the innominate artery takeoff, hemiarch replacement is reasonable in experienced centers, with the understanding that operative mortality and risk of stroke may be increased. Total arch replacement is reasonable in patients with BAV undergoing AVR with a mid-aortic arch diameter of $4.5 \mathrm{~cm}$ or greater as measured orthogonally by volume-rendered, cross-sectional imaging reconstructions. However, such pathology is rare and usually found in patients with BAV with other causes of aortic arch dilation (eg, previous aortic coarctation repair or aortic dissection, concomitant connective tissue disorder, Turner syndrome). Patients with BAV requiring complex elective aortic arch surgery should be referred to high-volume centers with established results. ${ }^{37,38}$

\section{MEDICAL MANAGEMENT \\ Follow-up Aortic Imaging}

Imaging of the aorta early after surgical correction is aimed at detecting anastomotic leaks and pseudoaneurysms, as well as establishing a baseline for future comparisons. Electrocardiogram-gated cardiac CT may be preferred to nongated CT angiography or TTE for early postoperative surveillance, because echocardiography is often limited by the presence of prosthetic aortic valves and therefore may miss periannular or anastomotic dehiscence. In younger individuals (aged $<50$ years), however, repeat CT examinations should be used with caution to avoid the risk of radiation-induced malignancy. In such instances, MRI is preferable.

The interval at which repeat imaging is performed after aortic surgery is often dictated by the extent of the initial operation and whether areas of aortic dilatation were not addressed during the initial surgery. In the absence of residual aortic dilation/pathology, it is reasonable to suggest that the entire aorta be imaged by CT or MRI 1 year after replacement and then as directed by clinical circumstances or evidence of aortic dilatation/pathology from that point forward 
TABLE 4. Recommendations for postsurgical repair, medical management, and watchful waiting

\begin{tabular}{|c|c|}
\hline Recommendation & Class/LOE \\
\hline $\begin{array}{l}\text { Radiologic imaging (with CTA or MRA) may be } \\
\text { performed after aortic surgery to establish a } \\
\text { postrepair baseline. }\end{array}$ & $\mathrm{IIb} / \mathrm{C}$ \\
\hline $\begin{array}{l}\text { Ongoing postoperative surveillance intervals } \\
\text { should be individualized on the basis of the } \\
\text { clinical, anatomic, and surgical features. In the } \\
\text { presence of residual aortic dilation/pathology, it } \\
\text { is reasonable to image the entire aorta every } \\
3-5 \text { y by CT or MRI after repair. }\end{array}$ & $\mathrm{IIa} / \mathrm{B}^{6,13,15-17,21}$ \\
\hline $\begin{array}{l}\text { MRI should be considered for repeat examinations } \\
\text { in an adolescent or in the adult population aged } \\
<50 \mathrm{y} \text {. }\end{array}$ & $\mathrm{IIa} / \mathrm{B}^{18}$ \\
\hline $\begin{array}{l}\text { Treatment of hypertension is recommended } \\
\text { according to country- and region-specific } \\
\text { guidelines. }\end{array}$ & $\mathrm{I} / \mathrm{C}^{13,53-57}$ \\
\hline $\begin{array}{l}\text { Beta-blockers and inhibitors of the renin- } \\
\text { angiotensin system should be considered for } \\
\text { blood pressure control based on evidence } \\
\text { extrapolated from connective tissue disease } \\
\text { populations. Nonpharmacologic approaches } \\
\text { (salt reduction, weight reduction) should be } \\
\text { advocated as part of blood pressure control } \\
\text { strategies. }\end{array}$ & $\mathrm{IIa} / \mathrm{C}^{13,53-55}$ \\
\hline $\begin{array}{l}\text { Patients with aortic aneurysms that are at or near } \\
\text { surgical thresholds for correction should avoid } \\
\text { strenuous lifting, pushing, or straining that } \\
\text { would require a Valsalva maneuver. }\end{array}$ & $\mathrm{IIa} / \mathrm{C}^{3,36,48,49,58}$ \\
\hline $\begin{array}{l}\text { It is recommended to avoid heavy weight lifting or } \\
\text { competitive athletics involving isometric } \\
\text { exercise when the ascending aortic diameter is } \\
>45 \mathrm{~mm} \text {. }\end{array}$ & $\mathrm{I} / \mathrm{B}^{3,36,48,49,58}$ \\
\hline $\begin{array}{l}\text { Patients with BAV and dilated aorta should be } \\
\text { precluded from private driving if the ascending } \\
\text { aorta diameter is }>6.0 \text { and restricted from } \\
\text { commercial driving if the ascending thoracic } \\
\text { aorta diameter is }>5.5 \mathrm{~cm} \text {. }\end{array}$ & $\mathrm{IIa} / \mathrm{C}^{36,47}$ \\
\hline $\begin{array}{l}\text { It is recommended that prepregnancy evaluation } \\
\text { and postpregnancy management of women with } \\
\text { BAV with or without associated aortopathy be } \\
\text { performed by practitioners with expertise in the } \\
\text { management of pregnant women with heart } \\
\text { disease. }\end{array}$ & $\mathrm{I} / \mathrm{C}^{59}$ \\
\hline $\begin{array}{l}\text { First-degree relatives of patients with BAV should } \\
\text { undergo screening echocardiography. }\end{array}$ & $\mathrm{IIa} / \mathrm{B}^{52}$ \\
\hline
\end{tabular}

(Table 4). When possible, these studies should be performed at the same institution using similar imaging techniques and protocols to minimize variation.

\section{Medical Management and Watchful Waiting}

The medical management of patients with BAV aortopathy who are under surveillance consists mainly of blood pressure control, along with cardiovascular risk reduction via pharmacologic and nonpharmacologic measures. There are no randomized trials to help guide decision making in this specific patient group. Treating hypertension with beta-blockers or inhibitors of the renin-angiotensin system has been suggested, however, based largely on extrapolation from studies in the Marfan syndrome literature. ${ }^{36,46}$ At the present time, there are no data to support lower blood pressure thresholds for patients with dilated aortas in the setting of BAV, and therefore, country- and region-specific guidelines for treatment of hypertension should be followed. General counseling on nonpharmacologic approaches to cardiovascular risk reduction should be part of watchful waiting in patients with BAV aortopathy.

There are no specific recommendations regarding automobile driving in patients with BAV aortopathy in previously published guidelines. However, the Canadian Medical Association has recommended that patients with abdominal aortic aneurysm be precluded from driving when the rupture risk exceeds $10 \%$ per year. ${ }^{36}$ On the basis of the best available observational data, this threshold of risk is exceeded for thoracic aortic aneurysms greater than $6.0 \mathrm{~cm}$ in the ascending aorta or arch and greater than $6.5 \mathrm{~cm}$ in the descending aorta. A lower threshold for rupture risk is reasonable for patients performing commercial driving. ${ }^{36,47}$

Exercise prescription or restrictions should be individualized in patients with aortic aneurysms. Patients with previously repaired aortic dissection should avoid strenuous lifting, pushing, or straining that would require a Valsalva maneuver. $33,36,48,49$ Strenuous strength training may be dangerous for patients with BAV aortopathy, because aortic dissection has been linked to weight lifting. ${ }^{49}$ The proposed mechanism is transiently elevated blood pressure associated with isometric exercise or Valsalva maneuver. ${ }^{48}$ Heavy weight lifting or competitive athletics involving isometric exercise may trigger aortic dissection, and such activities should be avoided in patients with moderately dilated aortas (ie, $>45 \mathrm{~mm}$ ) or when there has been a significant interval increase in size. However, individuals with bicuspid aortopathy can (and should) undergo aerobic or endurance exercise because these exercises are beneficial for blood pressure lowering. ${ }^{50}$ If patients want to engage in vigorous aerobic exercise, one might consider performing a symptom-limited stress test to ensure that the patient does not have a hypertensive response to exercise. In patients with a normal bicuspid valve and no associated dilated aorta, no exercise restrictions are required. 


\section{Family Screening}

Most cases of BAV disease are sporadic, but familial clustering is not uncommon. Genetic studies have suggested an autosomal dominant pattern with incomplete penetrance and variable expressivity as the likely mode of inheritance. ${ }^{51}$ Approximately $10 \%$ of first-degree relatives have the disorder. ${ }^{52}$ Therefore, it is recommended that firstdegree relatives of patients with BAV are screened with echocardiography.

\section{CONCLUSIONS}

BAV disease with associated aortopathy is a complex condition with elusive genetics and controversial pathophysiology. By virtue of the high frequency of BAV disease in the general population, cardiac specialists should be familiar with current recommendations for assessment, monitoring, and treatment of this disorder.

The current document is an executive summary of a larger consensus statement that covers all major aspects of BAV aortopathy, including its natural history, phenotypic expression, histology and molecular pathomechanisms, imaging, indications for surgery, surveillance, and follow-up, and recommendations for future research (please see fulllength document on pages e41-e74 in this issue). Detailed recommendations are found in Tables 1 to 4 accompanying this executive summary, which are meant to serve as a guide to assist clinicians with the daily management of these complex patients.

\section{Conflict of Interest Statement}

Dr Borger reports personal fees from Edwards LifeSciences, Medtronic, St. Jude Medical, and Cryolife. All other authors have nothing to disclose with regard to commercial support.

\section{References}

1. Hoffman J, Kaplan S. The incidence of congenital heart disease. J Am Coll Cardiol. 2002;39:1890-900.

2. American College of Cardiology/American Heart Association Task Force on Practice Guidelines, Society of Cardiovascular Anesthesiologists, Society for Cardiovascular Angiography and Interventions, Society of Thoracic Surgeons, Bonow RO, Carabello BA, et al. ACC/AHA 2006 guidelines for the management of patients with valvular heart disease: a report of the American College of Cardiology/American Heart Association task force on practice guidelines (writing committee to revise the 1998 guidelines for the management of patients with valvular heart disease): developed in collaboration with the Society of Cardiovascular Anesthesiologists: endorsed by the Society for Cardiovascular Angiography and Interventions and the Society of Thoracic Surgeons. Circulation. 2006;114:e84-231.

3. Hiratzka LF, Bakris GL, Beckman JA, Bersin RM, Carr VF, Casey DE Jr, et al. 2010 ACCF/AHA/AATS/ACR/ASA/SCA/SCAI/SIR/STS/SVM guidelines for the diagnosis and management of patients with thoracic aortic disease: a report of the American College of Cardiology Foundation/American Heart Association task force on practice guidelines, American Association for Thoracic Surgery, American College of Radiology, American Stroke Association, Society of Cardiovascular Anesthesiologists, Society for Cardiovascular Angiography and Interventions, Society of Interventional Radiology, Society of Thoracic Surgeons, and Society for Vascular Medicine. Circulation. 2010;121:e266-369.
4. Nishimura RA, Otto CM, Bonow RO, Carabello BA, Erwin JP III, Guyton RA, et al. 2014 AHA/ACC guideline for the management of patients with valvular heart disease: a report of the American College of Cardiology/American Heart Association task force on practice guidelines. J Thorac Cardiovasc Surg. 2014; 148:e1-132.

5. Warnes CA, Williams RG, Bashore TM, Child JS, Connolly HM, Dearani JA, et al. ACC/AHA 2008 Guidelines for the management of adults with congenital heart disease: a report of the American College of Cardiology/American Heart Association task force on practice guidelines (writing committee to develop guidelines on the management of adults with congenital heart disease). Circulation. 2008;118:e714-833.

6. Erbel R, Aboyans V, Boileau C, Bossone E, Bartolomeo RD, Eggebrecht H, et al. 2014 ESC guidelines on the diagnosis and treatment of aortic diseases: document covering acute and chronic aortic diseases of the thoracic and abdominal aorta of the adult. The task force for the diagnosis and treatment of aortic diseases of the European Society of Cardiology (ESC). Eur Heart J. 2014;35:2873-926.

7. Vahanian A, Alfieri O, Andreotti F, Antunes MJ, Baron-Esquivias G, Baumgartner H, et al. Guidelines on the management of valvular heart disease (version 2012): the joint task force on the management of valvular heart disease of the European Society of Cardiology (ESC) and the European Association for Cardio-Thoracic Surgery (EACTS). Eur J Cardiothorac Surg. 2012;42:S1-44.

8. Hiratzka LF, Creager MA, Isselbacher EM, Svensson LG, 2014 AHA/ACC Guideline for the Management of Patients With Valvular Heart Disease Representative Members, et al. Surgery for aortic dilatation in patients with bicuspid aortic valves: a statement of clarification from the American College of Cardiology/American Heart Association task force on clinical practice guidelines. $J$ Thorac Cardiovasc Surg. 2016;151:959-66.

9. Michelena HI, Prakash SK, Della Corte A, Bissell MM, Anavekar N, Mathieu P, et al. Bicuspid aortic valve: identifying knowledge gaps and rising to the challenge from the international bicuspid aortic valve consortium (BAVCon). Circulation. 2014;129:2691-704.

10. Fedak PW, Verma S. Bicuspid aortopathy and the development of individualized resection strategies. J Thorac Cardiovasc Surg. 2014;148:2080-1.

11. Della Corte A. Phenotypic heterogeneity of bicuspid aortopathy: a potential key to decode the prognosis? Heart. 2014;100:96-7.

12. Verma S, Yanagawa B, Kalra S, Ruel M, Peterson MD, Yamashita MH, et al Knowledge, attitudes, and practice patterns in surgical management of bicuspid aortopathy: a survey of 100 cardiac surgeons. J Thorac Cardiovasc Surg. 2013; 146:1033-1040.e4.

13. Michelena HI, Della Corte A, Prakash SK, Milewicz DM, Evangelista A, Enriquez-Sarano M. Bicuspid aortic valve aortopathy in adults: incidence, etiology, and clinical significance. Int J Cardiol. 2015;201:400-7.

14. Schulz-Menger J, Bluemke DA, Bremerich J, Flamm SD, Fogel MA Friedrich MG, et al. Standardized image interpretation and post processing in cardiovascular magnetic resonance: Society for Cardiovascular Magnetic Resonance (SCMR) board of trustees task force on standardized post processing J Cardiovasc Magn Reson. 2013;15:35.

15. Detaint D, Michelena HI, Nkomo VT, Vahanian A, Jondeau G, Sarano ME Aortic dilatation patterns and rates in adults with bicuspid aortic valves: a comparative study with Marfan syndrome and degenerative aortopathy. Heart. 2014;100:126-34.

16. Della Corte A, Bancone C, Buonocore M, Dialetto G, Covino FE, Manduca S et al. Pattern of ascending aortic dimensions predicts the growth rate of the aorta in patients with bicuspid aortic valve. JACC Cardiovasc Imaging. 2013;6: 1301-10.

17. Eleid MF, Forde I, Edwards WD, Maleszewski JJ, Suri RM, Schaff HV, et al Type A aortic dissection in patients with bicuspid aortic valves: clinical and pathological comparison with tricuspid aortic valves. Heart. 2013;99:1668-74.

18. Goldstein SA, Evangelista A, Abbara S, Arai A, Asch FM, Badano LP, et al. Mul timodality imaging of diseases of the thoracic aorta in adults: from the American Society of Echocardiography and the European Association of Cardiovascular Imaging: endorsed by the Society of Cardiovascular Computed Tomography and Society for Cardiovascular Magnetic Resonance. J Am Soc Echocardiogr. 2015;28:119-82.

19. Borger MA, Preston M, Ivanov J, Fedak PW, Davierwala P, Armstrong S, et al Should the ascending aorta be replaced more frequently in patients with bicuspid aortic valve disease? J Thorac Cardiovasc Surg. 2004;128:677-83.

20. Michelena HI, Khanna AD, Mahoney D, Margaryan E, Topilsky Y, Suri RM et al. Incidence of aortic complications in patients with bicuspid aortic valves. JAMA. 2011;306:1104-12. 
21. McKellar SH, Michelena HI, Li Z, Schaff HV, Sundt TM III. Long-term risk of aortic events following aortic valve replacement in patients with bicuspid aortic valves. Am J Cardiol. 2010;106:1626-33.

22. Girdauskas E, Rouman M, Disha K, Espinoza A, Misfeld M, Borger MA, et al. Aortic dissection after previous aortic valve replacement for bicuspid aortic valve disease. J Am Coll Cardiol. 2015;66:1409-11.

23. Park CB, Greason KL, Suri RM, Michelena HI, Schaff HV, Sundt TM III. Should the proximal arch be routinely replaced in patients with bicuspid aortic valve disease and ascending aortic aneurysm? J Thorac Cardiovasc Surg. 2011;142:602-7.

24. Charitos EI, Stierle U, Petersen M, Mohamed SA, Hanke T, Schmidtke C, et al. The fate of the bicuspid valve aortopathy after aortic valve replacement. Eur J Cardiothorac Surg. 2014;45:e128-35.

25. Regeer MV, Stierle U, Petersen M, Mohamed SA, Hanke T, Schmidtke C, et al. Effect of aortic valve replacement on aortic root dilatation rate in patients with bicuspid and tricuspid aortic valves. Ann Thorac Surg. 2016;102:1981-7.

26. Garrido-Olivares L, Maganti M, Armstrong S, David TE. Clinical outcomes of aortic root replacement after previous aortic root replacement. J Thorac Cardiovasc Surg. 2013;146:611-5.

27. Vohra HA, Whistance RN, De Kerchove L, Punjabi P, El Khoury G. Valve preserving surgery on the bicuspid aortic valve. Eur J Cardiothorac Surg. 2013;43:888-98.

28. Svensson LG, Al Kindi AH, Vivacqua A, Pettersson GB, Gillinov AM, Mihaljevic T, et al. Long-term durability of bicuspid aortic valve repair. Ann Thorac Surg. 2014;97:1539-48.

29. Parish LM, Gorman JH III, Kahn S, Plappert T, St John-Sutton MG, Bavaria JE, et al. Aortic size in acute type A dissection: implications for preventive ascending aortic replacement. Eur J Cardiothorac Surg. 2009;35:941-6.

30. Pape LA, Tsai TT, Isselbacher EM, Oh JK, O'Gara PT, Evangelista A, et al. Aortic diameter $>$ or $=5.5 \mathrm{~cm}$ is not a good predictor of type A aortic dissection: observations from the international registry of acute aortic dissection (IRAD) Circulation. 2007;116:1120-7.

31. Davies RR, Gallo A, Coady MA, Tellides G, Botta DM, Burke B, et al. Novel measurement of relative aortic size predicts rupture of thoracic aortic aneurysms. Ann Thorac Surg. 2006;81:169-77.

32. Wojnarski CM, Svensson LG, Roselli EE, Idrees JJ, Lowry AM, Ehrlinger J, et al. Aortic dissection in patients with bicuspid aortic valve-associated aneurysms. Ann Thorac Surg. 2015;100:1666-74.

33. Masri A, Kalahasti V, Alkharabsheh S, Svensson LG, Sabik JF, Roselli EE, et al Characteristics and long-term outcomes of contemporary patients with bicuspid aortic valves. J Thorac Cardiovasc Surg. 2016;151:1650-1659.e1.

34. Kim JB, Spotnitz M, Lindsay ME, MacGillivray TE, Isselbacher EM, Sundt TM III. Risk of aortic dissection in the moderately dilated ascending aorta J Am Coll Cardiol. 2016;68:1209-19.

35. Itagaki S, Chikwe JP, Chiang YP, Egorova NN, Adams DH. Long-term risk for aortic complications after aortic valve replacement in patients with bicuspid aortic valve versus Marfan syndrome. J Am Coll Cardiol. 2015;65:2363-9.

36. Boodhwani M, Andelfinger G, Leipsic J, Lindsay T, McMurtry MS, Therrien J, et al. Canadian Cardiovascular Society position statement on the management of thoracic aortic disease. Can J Cardiol. 2014:30:577-89.

37. Miyata H, Motomura N, Ueda Y, Tsukihara H, Tabayashi K, Takamoto S. Toward quality improvement of thoracic aortic surgery: estimating volumeoutcome effect from nationwide survey. Eur J Cardiothorac Surg. 2009;36:517-21.

38. Gazoni LM, Speir AM, Kron IL, Fonner E, Crosby IK. Elective thoracic aortic aneurysm surgery: better outcomes from high-volume centers. J Am Coll Surg. 2010;210:855-60.

39. Michelena HI, Desjardins VA, Avierinos JF, Russo A, Nkomo VT, Sundt TM, et al. Natural history of asymptomatic patients with normally functioning or minimally dysfunctional bicuspid aortic valve in the community. Circulation. 2008; 117:2776-84

40. Tzemos N, Therrien J, Yip J, Thanassoulis G, Tremblay S, Jamorski MT, et al. Outcomes in adults with bicuspid aortic valves. JAMA. 2008;300:1317-25.
41. Etz CD, Zoli S, Brenner R, Roder F, Bischoff M, Bodian CA, et al. When to operate on the bicuspid valve patient with a modestly dilated ascending aorta. Ann Thorac Surg. 2010;90:1884-92.

42. Svensson LG, Kim KH, Blackstone EH, Rajeswaran J, Gillinov AM, Mihaljevic T, et al. Bicuspid aortic valve surgery with proactive ascending aorta repair. J Thorac Cardiovasc Surg. 2011;142:622-9, 629.e1-e3.

43. Coady MA, Stockwell PH, Robich MP, Poppas A, Sellke FW. Should aortas in patients with bicuspid aortic valve really be resected at an earlier stage than tricuspid? CON. Cardiol Clin. 2010;28:299-314.

44. Svensson LG, Adams DH, Bonow RO, Kouchoukos NT, Miller DC, O'Gara PT, et al. Aortic valve and ascending aorta guidelines for management and quality measures. Ann Thorac Surg. 2013;95:S1-66.

45. Park CB, Greason KL, Suri RM, Michelena HI, Schaff HV, Sundt TM III. Fate of nonreplaced sinuses of Valsalva in bicuspid aortic valve disease. J Thorac Cardiovasc Surg. 2011:142:278-84.

46. Verma S, Siu SC. Aortic dilatation in patients with bicuspid aortic valve. $N$ Engl J Med. 2014:370:1920-9.

47. Canadian Medical Association. CMA Driver's Guide: Determining Medical Fitness to Operate Motor Vehicles. Toronto, Canada: Canadian Medical Association; 2012

48. Williams MA, Haskell WL, Ades PA, Amsterdam EA, Bittner V, Franklin BA, et al. Resistance exercise in individuals with and without cardiovascular disease: 2007 update: a scientific statement from the American Heart Association council on clinical cardiology and council on nutrition, physical activity, and metabolism. Circulation. 2007;116:572-84.

49. Hatzaras I, Tranquilli M, Coady M, Barrett PM, Bible J, Elefteriades JA. Weight lifting and aortic dissection: more evidence for a connection. Cardiology. 2007; 107:103-6.

50. Cornelissen VA, Buys R, Smart NA. Endurance exercise beneficially affects ambulatory blood pressure: a systematic review and meta-analysis. J Hypertens. 2013;31:639-48.

51. Laforest B, Nemer M. Genetic insights into bicuspid aortic valve formation. Cardiol Res Pract. 2012;2012:180297.

52. Hales AR, Mahle WT. Echocardiography screening of siblings of children with bicuspid aortic valve. Pediatrics. 2014;133:e1212-7.

53. Chun AS, Elefteriades JA, Mukherjee SK. Medical treatment for thoracic aortic aneurysm - much more work to be done. Prog Cardiovasc Dis. 2013;56:103-8.

54. Danyi P, Elefteriades JA, Jovin IS. Medical therapy of thoracic aortic aneurysms: are we there yet? Circulation. 2011;124:1469-76.

55. Ziganshin BA, Mukherjee SK, Elefteriades JA. Atenolol versus losartan in Mar fan's syndrome. N Engl J Med. 2015:372:977-8.

56. Appel LJ, Brands MW, Daniels SR, Karanja N, Elmer PJ, Sacks FM, et al. Dietary approaches to prevent and treat hypertension: a scientific statement from the American Heart Association. Hypertension. 2006;47:296-308.

57. Go AS, Bauman MA, Coleman King SM, Fonarow GC, Lawrence W, Williams KA, et al. An effective approach to high blood pressure control: a science advisory from the American Heart Association, the American College of Cardiology, and the centers for disease control and prevention. Hypertension. 2014;63: $878-85$

58. Braverman AC, Harris KM, Kovacs RJ, Maron BJ, American Heart Association Electrocardiography and Arrhythmias Committee of Council on Clinical Cardiology, Council on Cardiovascular Disease in Young, et al. Eligibility and disqualification recommendations for competitive athletes with cardiovascular abnormalities: task force 7: aortic diseases, including Marfan syndrome: a scientific statement from the American Heart Association and American College of Cardiology. Circulation. 2015;132: e303-9.

59. McKellar SH, MacDonald RJ, Michelena HI, Connolly HM, Sundt TM III. Frequency of cardiovascular events in women with a congenitally bicuspid aortic valve in a single community and effect of pregnancy on events. Am J Cardiol. 2011;107:96-9. 